\title{
A PROFILE OF PROFESSIONAL NURSING PRACTICE IN THE PRIVATE SECTOR IN THE R.S.A.
}

\author{
Silvia Pera
}

\section{Abstract}

The purpose of this study was to develop a profile of professional nursing practice in private enterprise health care services in the Republic of South Africa. In the light of the future health care needs and the relationship between the private and public sector health care establishments, information about the role and task of the professional nurse was needed. Information would provide a data base about the registered nurse and so facilitate future health care planning.

An exploratory field study was undertaken to locate the various work environments of the registered nurse in four statistical urban regions.

Questionnaires were handed out and collected from a proportional stratified sample of professional nurses who were working in thirteen types of health care environments in the period between I June 1983 and 30 September 1983. A return rate of 68 percent yielded 340 completed questionnaires from 501 registered nurses.

The study revealed that the majority of nurses in the private sector were relatively young. White, female,

English-speaking professionals who were practising in four broad areas of heallh care:

- Custodial care environments such as residential homes for the aged. institutions for the chronic sick and frail aged, homes for children and homes for the adult handicapped.

- Hospitals and related special health centres catering for drug addicts, alcoholics and patients suffering from psychiatric/nervous disorders.

- Institutions for child and adult education which included crèches/nursery schools, primary and secondary boarding schools, special schools for the handicapped and university based student health centres.

- Medical and dental consulting room practices.

- Other entrepreneurial employment settings such as business and industrial occupational health care services, nursing service agencies, and mobile emergency care units.

\section{Uittreksel}

Die doel van hierdie studie was om 'n profiel van die professionele verpleegpraktyk in die gesondheidsorgdienste van privaat ondernemings in die Republiek van Suid-Afrika te ontwikkel. In die lig van toekomstige gesondheidsorgbehoeftes en die verhouding tussen die private en openbare sektor was inligting oor die rol en take van die professionele verpleegkundige nodig.

Inligting sal 'n databasis voorsien oor die geregistreerde verpleegkundige en vergemaklik toekomstige gesondheidsorgbeplanning.

in Verkennende veldstudie is onderneem om die verskeidenheid werksomgewings van die geregistreerde verpleegkundige in vier statistiese stedelike gebiede vas te stel. Aan in eweredige gestrattfiseerde steekproef van professionele verpleegkundiges wat in dertien tipes gesondheidsorgomgewings werksaam was gedurende die periode tussen I Junie 1983 en 30 September 1983, is vraelyste uitgegee en versamel. 'n Terugvoerkoers van 68 persent is hehaal met 340 voltooide vraelyste van 501 geregistreerde verpleegkundiges wast terugontvang is.

Die studie het bewys dat die meerderheid professionele verpleegkundiges in die privaat sektor relatief jonk, blank, vroulik,

Engelssprekend is en in vier breë areas van gesondheidsorg praktiseer:

- Bewaarsorgomgewings soos tehuise vir bejaardes, inrigtings vir die chroniese siekes en verswakte bejaardes, tehuise vir kinders en inrigtings vir die volwasse gestremde.

- Hospitale en verwante spesiale gesondheidsentrums vir die dwelmverslaafdes, alkoholiste en pasiënte wat ly aan geestesafwykings/senuwee toestande.

- Inriglings vir kinder-en volwasse onderwys wat crèches, kleuterskole, primêre en sekondêre kosskole. spesiale skole vir die gestremde en universiteitsverbonde gesondheidsentrums insluit.

- Mediese en tandheelkundige spreekkamerpraktyk.

- Ander werkverskaffingsinstansies soos besighede en

beroepsgesondheidsdienste. verpleegagentskappe en mobiele noodsorgeenhede.
"Only if a country plans the whole of iss health services public and private will plans have a prospect of success."

Brian Abel-Smith

\section{INTRODUCTION}

South Africa is one of the few countries in the world where the free enterprise system of health care prevails. This type of health care system, once common, was typical of the United States of America during the early forties and, until a decade ago, in Australia.

Because of the apparent lack of a comprehensive picture of the type of service provided by professional nurses in various organisations and/or institutions which are conducted as (profit-making) businesses, this research attempted to provide a starting point for those in search of such a perspective.

The primary purpose of the study was to collect data to develop a profile of professional nursing practice in all types of health care and related settings in the private sector. Information is needed to identify the present role and responsibilities of this highly skilled professional health care worker whose field of practice lies within South Africa's free enterprise health care system. A greater involvement of nurses in both the public and private sectors is necessary if the provisions of the Health Act are to be realised within a stable economic milieu.

This abstract is based on the major findings derived from the analysis of the data related to five broad areas of nursing practice in the private sector. Due to the extensive nature of the study, the findings pertinent to each area of practice will be dealt with in subsequent abstracts.

\section{AIMS OF THE STUDY}

The study sought to develop a profile of professional nursing practice in all fields of nursing identified in health care services in the private sector. The study particularly attempted to answer the following questions:

- What are the biographical characteristics of the professional nurse who has elected to work in private enterprise health care and/or related nursing services?

-What is her socio-economic status? 
- How concerned is the nurse in the private sector with professional affiliation and self-development?

- What is the extent of her administrative/managerial responsibilities?

- What is the nurse's teaching role?

- Which nursing and related diagnostic/therapeutic activities does the nurse undertake?

- What is the nursing role structure within the practice area?

\section{STUDY PROCEDURES}

A review of the literature was undertaken to determine the breadth of the problem and in order to give some orientation to the study in terms of what should be investigated. The research questions were decided upon and a questionnaire developed for the purpose of gathering the data. An exploratory field study was undertaken and the target population of 3140 professional nurses identified in four urban statistical regions, one in each province.

\section{Development of the research methodology} In order to be able to generalise about the registered nurse working in the private enterprise health care system, one requires a sample which, one must be reasonably sure, will accurately represent the total population of such nurses working in both urban and rural areas. A survey of the literature revealed that no significant research had been done in this field. Various factors contributed towards defining the research area, developing the method used to identify work

environments, and selecting the population elements.

\section{Determining the target population} A number of key factors related to population distribution patterns and trends in urbanisation and industrialisation played an important role in determining the target population.

Rural-urban differentials were examined and carefully weighed in the pre-selection phase. The geographical distribution patterns of different population groups with increased urbanisation tendencies were primary factors which had to be carefully considered before delineating the target population.

Secondary factors that were taken into account centred around work opportunities and the general socioeconomic development of population groups. Urban areas usually offer more and better job opportunities and training facilities for all population groups. Large concentrations of health service personnel are usually found in these urban areas while cities generally offer specialised services, particularly hospital and nursing services.

After studying the population distribution patterns with the concomitant socio-economic factors, it was decided to select a geographic region with the highest White population count in each of the four provinces.

\section{Identifying the population}

An extensive field search was undertaken to locate the various work environments in which professional nurses could be working, and to ascertain the total number of registered nurses from which a reliable sample could be taken. A total of 3140 professional nurses were identified.

The sample elements were divided into relevant sub-units according to the types of work environments identified.

The sample size selected constituted ten percent of the finite population of registered nurses ( 3 140) identified in Table 1 and five percent of the total number of medical practitioners identified.

\section{The sample}

Work settings were stratified according to type of nursing field and a total of 535 registered nurses comprised the total sample. The selection process ensured that the final number was a random sample of the total number available. Thirty four registered nurses were sampled in the statistical region in the Orange Free State which was ultimately used for the pilot study. (See table 1)

\section{Categorisation of practice areas}

The sample of professional nurses practising in thirteen fields of nursing were categorised according to five broad areas of practice in the private sector which offered employment opportunities to the registered nurses. (See table 1)

Custodial health care settings offer work opportunities for nurses in homes and institutions for the aged and chronic sick, homes for children and homes for adult handicapped persons. Private hospitals and special health centres are likewise primary employment settings for registered nurses in this country.

Institutions for child and adult education offer employment opportunities for nurses in crèches/nursery schools, in private primary and secondary boarding schools, special schools for the handicapped and in student health care centres. Other entrepreneurial organisations such as business and industrial firms, private nursing service agencies and mobile emergency care units, offer job opportunities for professional nurses in specialist health care areas. Medical and dental solo and partnership practices are major employment settings for this category of nurse.

\section{Data collection}

The seven part questionnaire containing both closed and open-ended questions was handed out and collected from a proportional stratified sample of professional nurses in the period between 1 June 1983 and 30 September 1983. A return rate of 68 percent yielded 340 completed questionnaires from 501 registered nurses.

\section{Statistical analysis of responses}

Analysis of the data was performed in two parts. The first stage was the analysis of the responses to the pilot study.

The second stage was the analysis of the 340 usable questionnaires. The processing, grouping and computation of the descriptive statistics was accomplished with the use of the Statistical Package for the Social Sciences (SPSS).

\section{FINDINGS, CONCLUSIONS AND RECOMMENDATIONS}

The findings, directed towards elucidating the major objectives of the study as represented by the research questions, together with the conclusions and the recommendations formed as a result of the analysis of the data are submitted to improve health care delivery by nurses working in private enterprise health service settings.

\section{What are the biographical characteristics} of the professional nurses who have elected to work in health care or related nursing service settings in the private sector? The registered nurse practising in health care fields in the private sector may be described as a relatively young to middleaged, White English-speaking professional who holds two basic nursing qualification

* Sex

It was found that the distribution according to sex within each type of employment setting was unbalanced - as figures in Table II show.

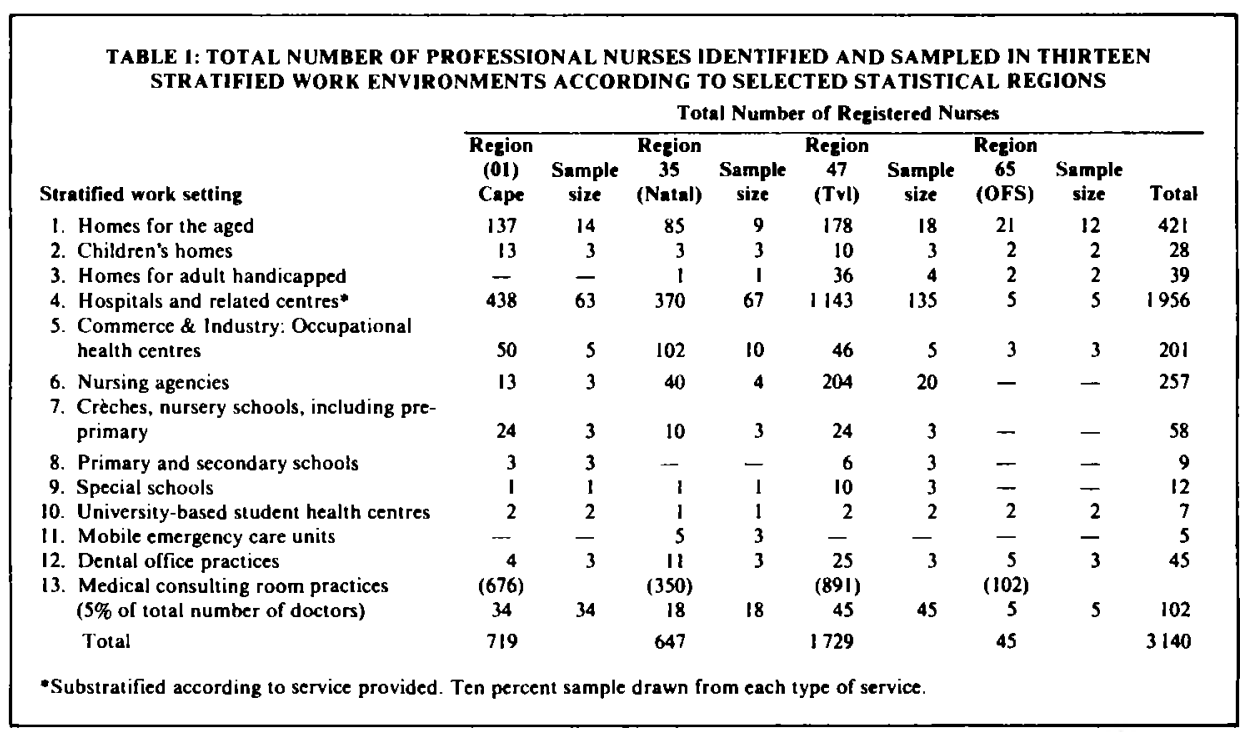




\begin{tabular}{|c|c|c|c|}
\hline \multicolumn{4}{|c|}{$\begin{array}{l}\text { TABEL. II: DISTRIBUTION OF RESPONDENTS BY SEX } \\
\text { ACCORDING TO AREA OF PRACTICE }(\mathrm{N}=340)\end{array}$} \\
\hline Practice area & Male & Female & Total \\
\hline $\begin{array}{l}\text { Custodial and related health care } \\
\text { settings }\end{array}$ & 1 & 75 & 76 \\
\hline $\begin{array}{l}\text { Hospitals and related special health } \\
\text { centres }\end{array}$ & 5 & 147 & 152 \\
\hline $\begin{array}{l}\text { Institutions for child and adult } \\
\text { education }\end{array}$ & - & 20 & 20 \\
\hline $\begin{array}{l}\text { Entrepreneurial employment settings } \\
\text { Medical and dental consulting room } \\
\text { practices }\end{array}$ & - & $\begin{array}{l}30 \\
62\end{array}$ & 30 \\
\hline Total & $6(2 \%)$ & $334(98 \%)$ & 340 \\
\hline
\end{tabular}

Although the nursing profession in this country is predominantly female, recent figures show that the percentage of male registered nurses in the nursing force is steadily increasing; in 1981, they represented $2,94 \%$, and in $1983,5,97 \%$ of the total number of persons on the register $(6$, p. 1-6).

The rise in male participation rates could be attributed to and influenced by the current economic climate; fewer job opportunities including retrenchment terns together with the improved salary structures and conditions of service for nurses in government employment.

\section{*Ethnicity}

The large majority of nurses in the sample were White (92\%); most were Englishspeaking (84\%); thirty-nine were Afrikaans (11\%); six spoke another European language as a home language (2\%), while nine spoke a Black ethnic language as a home language $(5 \%)$.

The twenty-seven nurses who represented the three other population groups $(8 \%)$ and who were employed in White private sector health services were mainly hospital-based. The number of Coloured and Black nurses in the sample were twice the number of Asian nurses. It should be noted however that the registered nurse population in South Africa is lowest among the Asiatic nurses. In the health sector in this country both blic and private sectors are employers of professional nurses and will in future be obliged to take into account the demands for nurse manpower requirements in order to maintain a dynamic equilibrium.

\section{*Age}

Of interest with regard to the age

distribution of the respondent sample was that most young newly qualified nurses in the age category $21-29$ years were working in institutions for child and adu't education, in other entrepreneurial employment settings as categorised, and in medical and dental consulting room practice settings. These practice settings offer challenges to the nurse who is ready to expand her range and competence. The largest number of nurses in the age group 50-59 years, on the other hand, were nurses in custodial care settings. The nurse in this setting often works in isolation and is solely responsible for the motivational and situational events that confront their patients. The highest number of nurses in the age group 30-39 years were working in hospital and related special health centres.
This is the period when the professional nurse has the most responsibilities to cope with in regard to occupational advancement and caring for older children. While most nurses in the sample were younger than 49 years, the largest percentage were in the age group 21-29 years.

\section{Marital status}

Most nurses in the survey were married or had been married; only thirty two percent were single, but more than half the respondents were solo wage earners as a result of divorce, widowhood or the fact that the spouse was not economically active. The largest percentage of respondents who had never married were the hospital-based nurses. Contributory factors may include the following:

- Private hospitals offer employment opportunities to the newly qualified registered nurse or the nurse who has just completed a post registration course and to nurse immigrants at a competitive salary and more flexible work hours - a fact which suits their particular social lifestyles.

- The non-educationally oriented environment of most private hospitals attracts the young professional who wishes to escape from the responsibilities of a training hospital.

- A few of the larger private hospitals in the study offered training facilities for nurses who were undergoing basic courses.

The percentage of nurses who were solo wage earners was highest in the groups of nurses working in hospitals, special health centres, and institutions for child and adult education.

\section{*Children}

Fifty-two percent of the respondents had children but most of the two-hundred-andone children were 13 years and older (47\%). Of the remaining children, twentynine percent were of schoolgoing age, twelve percent were in their third year and older, while only twenty-four were younger than two years of age (12\%). Fifty-eight percent of the one-hundred-and-sixtyseven nurses who had children had need of child minders/care services for their children. Most of those nurses made use of either a domestic or a family member as a child minder for this purpose while they were at work. The reason for this could be the lack of crèche facilities in the work place, coupled with the high cost of child care services.

\section{*Spouse}

The largest majority respondents reported that the spouse supported their decision to work and follow a career. Paul Montagna maintains that men are becoming more willing to share housework and child rearing and to help their wives to find occupational fulfilment. But he points out that, for working class wives, the situation is different. They have to work to help support the family $(4$, p. 403$)$. It was found that most nurses in all practice areas were married to spouses who were in whitecollar occupations.
Which basic and post-registration nursing qualifications do they hold?

The registered nurse in South Africa is a professional person who carries out diagnostic and therapeutic nursing procedures according to legislation in an independent or (where necessary) in an interdependent capacity. To obtain registration in one of the three basic nursing courses, the nurse must have had at least twelve years schooling and have undergone at least three to four and a half years post-secondary instruction in nursing to obtain a basic nursing diploma or degree.

\section{* Basic nursing registrations}

Responses revealed that three-hundredand-thirty-seven registered nurses $(99 \%)$ in the sample were general trained; twohundred-and-twelve were qualified midwives (62\%). The percentage of nurses holding the three basic nursing registrations in each practice area is illustrated in Figure 1. (Overleaf)

It is evident that a large proportion of professional nurses who were working in private sector health services at the time of the survey are not fully equipped to provide a comprehensive health service within their employment settings. The Health Act, No. 63 of 1977, together with the announcement of the National Health Facilities Plan in 1980, provided the medium for a comprehensive health service for the total population of the Republic of South Africa. To meet this challenge, the S.A. Nursing Council introduced a comprehensive basic diploma course at the end of 1982. This four-year course includes General Nursing, Midwifery, Psychiatric Nursing, and Community Nursing. All these specialities will prepare and enable future nurses to deliver a comprehensive service in both public and private sector health services.

\section{*Post-registration qualifications}

A wide variety of post-registration courses for registered nurses are available in this country to provide for a competent nursing force. These courses equip the nurse to provide specialist and comprehensive services to meet the growing needs of the population.

\section{Clinical qualifications}

The following table reflects the type of qualification held by the sample of nurses in each area of practice. (See overleaf)

Figures reveal that all practice areas have a small number of nurses with specialised knowledge and skills which can benefit the service if they are fully utilised. Excluding the three nurses who hold the Diploma in Operating Theatre Technique and who are employed in custodial cre settings and institutions for child and adult education most of these nurses were practising in environments where the patient will benefit directly the additional skills and knowledge the professional nurse had gained for herself through postregistration studies. 
FIGURE I. BASIC NURSING QUALIFICATIONS: PERCENTAGES BASED ON TOTAL NURSES IN EACH PRACTICE AREA.

GENERAL NURSING

MIDWIFERY

PSYCHIATRIC NURSING

$100 \%$

$100 \%$

$99 \%$

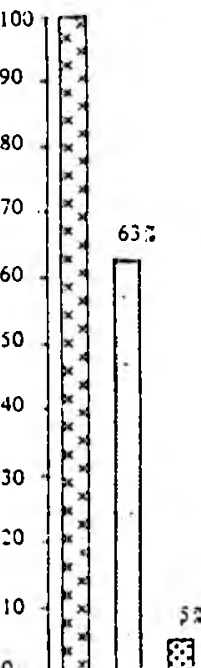

CUSTODIAL CARE
SETTINGS SETTINGS

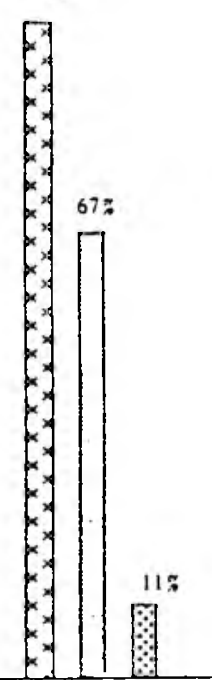

HOSPITALS/ SPECIAL. HEALTH CENTRES

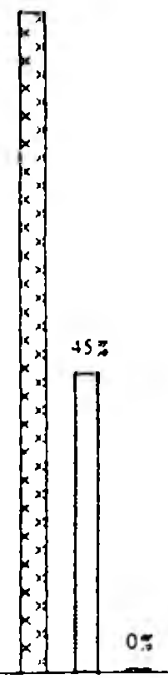

INSTITUTIONS FOR CHILD AND ADULT
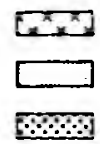

98\%
7

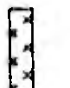

3

67\%

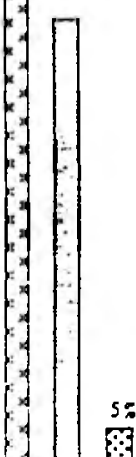

ENTREPRENEURIAL ORGANISATIONS

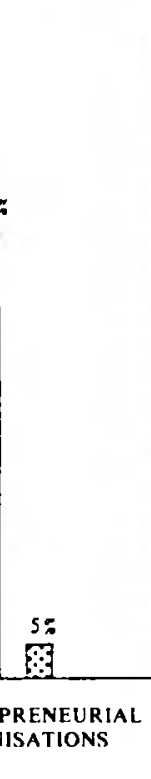

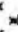

.

$53 \%$

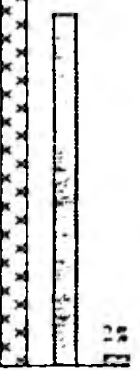

MEDICAL \& DENTAL

TABI.E III: CLINICAL, NURSING QUALIFICATIONS HELD BY NURSES IN EACH AREA OF PRACTICE

\begin{tabular}{|c|c|c|}
\hline $\begin{array}{c}\text { Custodial } \\
\text { care services } \\
(N=76)\end{array}$ & $\begin{array}{l}\text { Hospitals/ } \\
\text { healith centress } \\
\text { (N = 152) }\end{array}$ & $\begin{array}{l}\text { Institutions } \\
\text { for education or } \\
(\mathrm{N}=\mathbf{2 0})\end{array}$ \\
\hline 2 & - & - \\
\hline$i$ & 3 & - \\
\hline 2 & - & 1 \\
\hline 4 & - & - \\
\hline$i$ & - & - \\
\hline$i$ & 3 & - \\
\hline- & 13 & - \\
\hline- & 2 & - \\
\hline- & 5 & - \\
\hline- & $i$ & - \\
\hline 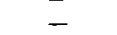 & 3 & 1 \\
\hline- & 1 & - \\
\hline- & 2 & - \\
\hline- & 2 & - \\
\hline- & - & - \\
\hline 11 & 35 & 2 \\
\hline
\end{tabular}

Medical/ dental practices Total

Type of Diploma/Certificate General nurse instructor Orthopaedic nursing Operating theatre technique Gerialric nursing science Disıricı nursing

Community health nursing

Intensive nursing

Ophthalmic nurssng

Pacdialric nursing

Advanced Midwifery and Neonalal Nursing

Occupational health nursing

Advanced Psychiatric Nursing Science

Advanced Pacdiatric and Neonatal Nursing

District nursing neurial $(N=30) \quad(N=62)$ Total
$(\mathbf{N}=\mathbf{3 4 0})$

\section{Non-clinical qualifications}

A number of private hospitals in each of the three statistical regions selected for the study offered training facilities for certain categories of nurses. Responses revealed that only two nurses in the sample of hospital-based nurses had non-clinical qualifications. One nurse held the Diploma in Nursing Administration while the other held the Diploma in Nursing Education. Of interest is the fact that the only other nurse who held a Diploma in Nursing Education was employed in a medical consulting room practice.

\section{University qualifications}

Findings revealed that fourteen nurses were university graduates. Thirteen nurses reported that they held basic bachelor's degrees in nursing (4\%); six of these were working in hospitals; two were employed by entrepreneurial organisations; four were in medical consulting room practices. One nurse in a custodial care setting held an honours degree in addition to her bachelor's degree. The only other nurse with a degree was working for a doctor and held a non-nursing bachelor's degree.

What is her socio-economic status? Findings concerned with the social and economic conditions of the nurses practising in each of the five practice areas revealed that, although the nurse in the private sector is able to make an independent decision regarding her practice field, place of work, direct patient care opportunities, and work shifts, the work week schedules were found to be similar to those in governmental health services. Responses also revealed that nurses in private enterprise health services have limited fringe benefits, promotion and continuing education opportunities.

Where and in what capacity is this category of nurse working?

Although the large majority of nurses in five areas of practice were employees (97\%), eleven were found to be working proprietors (3\%). These nurses were the owners of institutions for the aged, small private hospitals, a crèche, and a nursing service agency. Of interest regarding job titles was that while most held nursing titles only a small number of nurses held non-nursing titles such as director, nursery school teacher, child care worker, medical secretary, and dental secretary. These titles denote job status and the type of work performed.

What is the pattern of employment? Only thirty nurses in the study were employed in temporary posts (9\%). The remaining number all occupied permanent positions in their respective employment organisations. Of interest is that a number of nurses were in permanent part-time posts; fifty-six nurses reported that they were part-time workers (16\%). Eighty-four percent of the sampled nurses employed in private sector health services were in fulltime posts; only fifty-four nurses occupied part-time posts. A comparative profile of all the employed registered nurses in America in 1980 revealed that sixty-seven percent of the nurses in that country worked full time (2, p. 486).

The number of nurses working flexi-time hours is insignificant (3\%), if one considers choice of work hours as a factor for selecting private sector employment. Of the ten nurses who had this privilege, two were hospital-based, four were in custodial care settings, three were private duty nurses, while one was a medical secretary.

How far is the place of work from the home environment?

In this country, the vast majority of registered nurses are not only female; a significant number are also either married in dual career families or are solo parents who have to balance the demands of home and a career. Montagna maintains that if the wife takes on a professional role, this does not imply a dramatic change for the family. Studies have revealed that wives are still expected to maintain their domestic roles as house cleaners, child minders and cooks, while the husbands assist when necessary. The woman who follows a career has to channel energies into two roles - home and profession. The increasing number of hours worked by professional people further complicates the difficulties encountered by women in these dual career families. When the decision is made about where the family should live, the husband's job is generally always given prior consideration (4, p. 225).

It was believed that distance from the work place and travel time were influential factors which would determine the choice of work place by the nurse electing to work in the private sector. Findings revealed however that only half the sample of nurses in the study lived relatively close to their employment settings.

The sample of nurses employed by private boarding schools lived in flats or cottages on the school premises, but a few nurses in other practice areas also lived on the work premises. 
What kind of shift does the nurse work? Findings revealed that most nurses in all five areas of practice worked straight shifts. A number of nurses in the following employment settings still, however, work the broken-type shift: three in hospitals for the chronic sick and aged; thirty-one in hospitals and speciai health centres $(20 \%)$; one boarding school nurse; three mobile emergency care nurses, and one nurse employed in a medical consulting room practice. Hospital-based nurses are generally required to provide patient care services seven days a week for 24 hours a day. The social, psychological and physiological problems associated with providing a 24 hour nursing service for the institutionalised patient is perhaps one of the negative aspects of nursing and a determining factor in career selection. Between 1979 and 1983 there was an average total decrease of $5,3 \%$ per annum in all student nurses in South Africa, with the highest average yearly decrease of $9 \%$ in White student nurses ( 5, p. 35).

In which days of the week does the nurse generally work?

It was found that the sample of nurses worked twenty different shift patterns with the greatest variation in custodial type care settings. Less than forty percent of the nurses in custodial care and hospital settings had weekends free whereas about sixty percent employed in the other settings had this privilege.

It was evident that, in areas where twenty-four hour patient care services are provided, such as custodial care settings and in hospitals and related institutional settings, relatively fewer nurses have the privilege of having every weekend free. It is evident from responses, however, that even in this type of environment in the private sector every consideration was given to the most appropriate type of shift and shift rotation pattern for the service and the personnel.

It was found, in addition, that while host nurses in all fields of nursing were satisfied with their present jobs, many would consider returning to public sector employment. Specified work hours according to conditions of employment ranged from a six-hour work week up to sixty-eight hours per week, with most nurses working a 40-44 hour week. The hours actually worked by a number of nurses exceeded, however, their specified hours. A number of nurses were expected to be on call during their off-duty hours; some reported that they were reimbursed or given compensatory time off for overtime work, but a number of nurses in all practice areas received no compensation.

\section{How long has the nurse been working in} her present job?

Findings with regard to tenure revealed that the nurse who provided nursing care for patients in special health centres and in homes and institutions for the aged had been with their employers the longest; between 10 and 18 years. Nurses employed in hospitals, medical consulting rooms, homes for the handicapped and private duty nurses, 6 years. Those in children's homes, dental rooms and crèches, 4 years. Tenure in the remaining settings varied from 3 months to 2 years.

\section{What type of fringe benefits exist and how important are fringe benefits to the professional nurse?}

Findings revealed that occupational health nurses as a group were the only respondents among whom about fifty percent of the nurses received the highest number of fringe benefits: ten in all. Of the other nurses employed by entrepreneurial organisations, above fifty percent of the mobile emergency care nurses received three types, while less than half the sample of sixteen private duty nurses received one or more fringe benefits, above fifty percent of the nurses in custodial care settings received three types, while those working in institutions for education received three. The three types received by most nurses were paid sick leave, weekends off, and medical scheme benefit.

Figure 2 will show the percentage of nurses who received fringe benefits and the importance attributed to each type.

Three fringe benefits were rated as important by above fifty percent of the sample of 340 nurses who received them, namely, sick leave, weekends free, and uniform allowance. Of interest in the findings on the response to the open-end question on fringe benefits is that other types of benefits were received by some nurses. These were mainly free housing facilities, parking, and school holidays. No respondent indicated that they had the

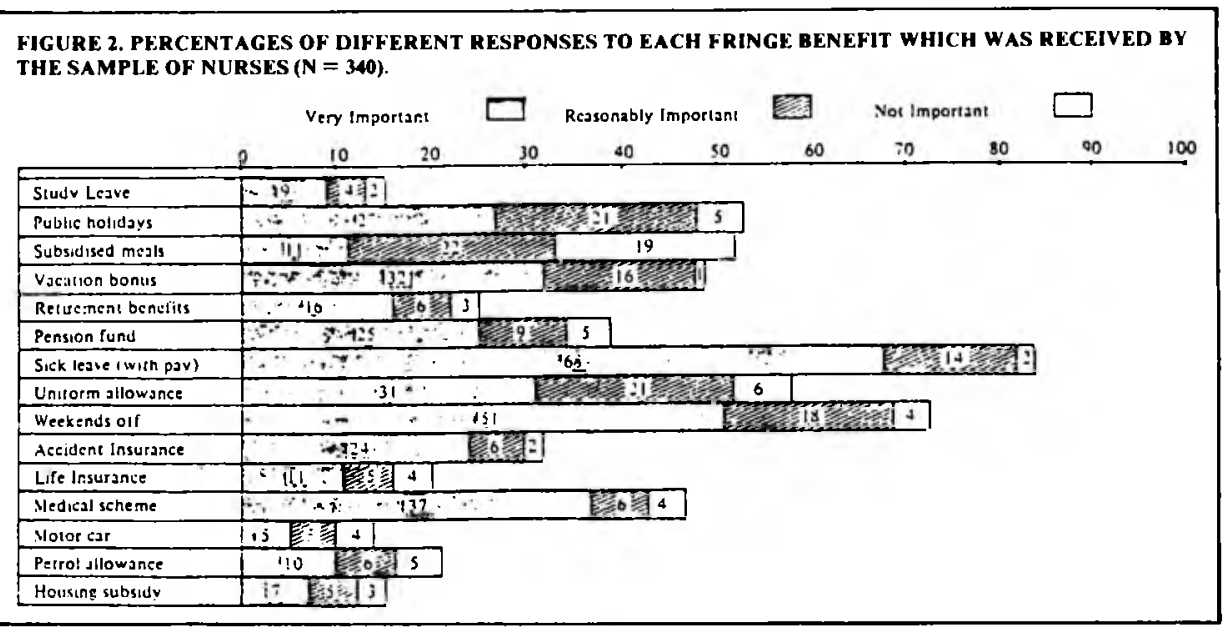

maternity leave benefits which are received by registered nurses in the public sector. In the period 1979-1983, the South African Nursing Association laid proposals before the Commission of Administration that maternity leave privileges for all categories of nursing personnel in governmental health services be investigated and, if approved, payments for such privileges be limited to two pregnancies $(5$, p. 22$)$.

What is the nurse's annual income? On 1 October 1982, the career-specific dispensation regarding salaries and the post structure of nursing personnel in the public sector came into operation. During the survey in the private sector in 1983, an attempt was made to determine the approximate earnings and nursing role structure within each work setting to develop comparative private sector post structures. Five distinct management levels emerged according to the authority and responsibility the following percentages of nurses respectively attached to the post occupied:

- proprietor/ownership level

- top-level manager/supervisor

- mid-level manager/supervisor

- first-line supervisor

- professional service level worker $49 \%$ Although one percent of the nurses sampled did not indicate what the level of authority of the post they held was, and four percent did not reveal their gross earnings, Figure 3 (overleaf) shows clearly that the largest percentage of nurses earned R5 000 and more, but less than R 10000 per annum. It may be assumed that these were the nurses who occupied professional service-level posts.

The salary scale compares favourably with salaries earned by nurses in the public sector holding a sister's post, now known as the professional nurse rank, with a salary adjustment of R2000. It became evident that, at the time of the survey, the salary of this level of nurse had not been increased in private health services.

Of interest regarding the higher incomes is that only four of the eleven nurse proprietors were earning in the same salary range as the nurse in the public sector who holds the post of Director-Nursing Services (whose salary is fixed at R30 255).

\section{Why has the registered nurse entered the} private sector?

It was found that reasons for taking a post in the private sector varied according to the practice area of the nurse to a limited extent. The nurse employed in custodial care settings and mobile emergency care nurses reported that being able to make their own decisions about the work had been a very important reason. Hospitalbased nurses and private duty nurses reported that it was because they had more opportunity to give direct patient care, while the nurses in special health centres stated that the work place was nearest their homes. Nurses employed in institutions for education and in medical and dental consulting rooms revealed that the work hours suited their family life styles. The next bar diagram depicts the rate of 
FIGURE 3. APPROXIMATE GROSS ANNUAL INCOME OF REGISTERED NURSES IN PRIVATE HEALTH CARE SERVICES: PERCENTAGES BASED ON TOTAL SAMPLE $(\mathbf{N}=340)$.

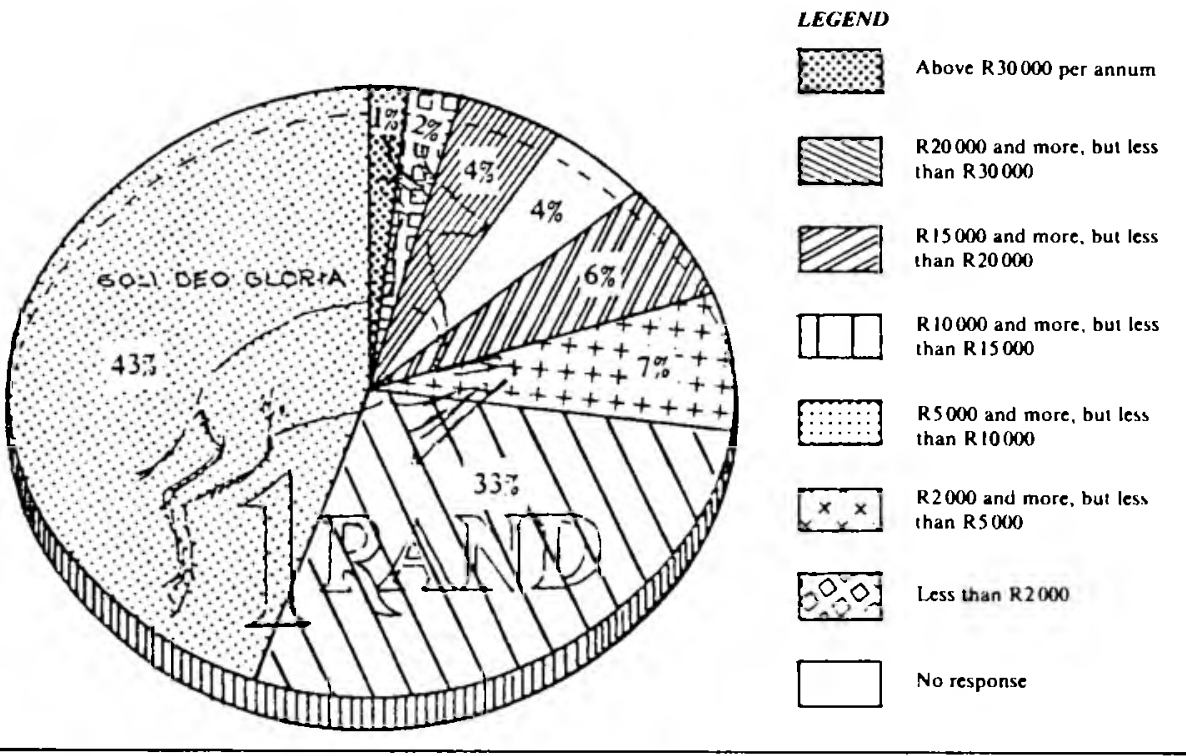

importance the sample of nurses attached to each of the eight factors. The factor receiving the highest response was "The hours of work suit your family life style". These findings are supported by the report of the Human Sciences Research Council on the working situation of nurses, which revealed that one out of every five nurses who had qualified in 1981 had resigned by 1983 from the profession mostly within three months after qualifying.

Inconvenient working hours seemed to be one of the major problems. It was found that two years after qualifying, half the study group were already married with commitments to homes and young children (1, p. 50).

\section{Conclusions}

The relatively young, mainly White, female, English-speaking registered nurses who select a private sector health service as career setting do this because they are able to work the hours which suit their family lifestyles and because they can work in practice environments where they can give direct patient care. Young newly wed nurses or those with pre-school children experience great difficulty in coping with family commitments when work hour patterns, night duty schedules and weekend shifts are inflexible. Most employment settings in private enterprise tend to offer a variety of shift schedules and many do not require the nurse to work over weekends such as in business and industrial occupational health services and all other forms of ambulatory care settings including medical and dental office practices.

Private hospitals, nursing homes for the aged and medical practitioners are the largest employers of professional nurses in private enterprise. The married nurse forms a large part of this sector's health service nursing force. Because of divorce, widowhood, or a spouse who is not economically active, most nurses in private enterprise are, however, solo wage earners. This trend is likely to increase because of the rise in unemployment and unelected retirement patterns currently experienced While many institutions providing health services in the private sector employ large numbers of enrolled nurses and nursing assistants of other racial groups, relatively few Black, Coloured and Asian registered nurses were sampled.

Relatively few nurses make use of child care facilities but tend to leave their children in the care of a domestic or family member while they are at work. Choice of work hours no doubt plays a role here together with the current economic climate since child care services are expensive. Few nurses in the private sector have, in addition, free or cheap crèche facilities as a fringe benefit.

Although nearly all the nurses are registered general nurses and more than half hold a second basic registration, very few nurses are psychiatric trained and even fewer hold post-registration clinical qualifications which will enable them to provide a comprehensive health care service.

A limited number of nurses in the private sector receive study leave benefits to enable them to acquire nursing skills which will assist them to meet the comprehensive needs of their patients. Only nine nurses (one in the OFS, one in the Cape, two in Natal and five in the Transvaal statistical regions) held the Diploma in Community Health Nursing Science. Provision has been made for the professional nurse in this country to acquire additional knowledge and skills through post-registration courses. A wide variety of post-registration courses for registered nurses have been established by the SA Nursing Council. Most universities offer post basic degrees in nursing which can be taken either full time or part time. The University of South Africa provides unlimited opportunities for the nurse who is unable to leave her home or work environment through distance teaching instruction. The nursing education programme in South Africa has provided for the needs of the professional nurse to practice in a variety of health service fields.

\section{Recommendations}

- Employing authorities and employers: should provide opportunities for the professional nurse to undertake relevant nursing courses which will enable her to provide a more effective health service within the work setting.

- Employers of nurses in occupational settings which cannot provide a promotion pyramid should offer an additional increment as an incentive motivating factor for each additional nursing qualification through postdegree courses obtained.

- Employers of nurses should bring fringe benefits on to a par with those offered by governmental services -- particularly maternity leave benefits, overtime pay, free or low-cost creche facilities.

How concerned is the nurse in the private sector with professional affiliation and selfdevelopment

Findings revealed that most nurses in the study registered annually with the $S A$ Nursing Council, but a number reported that they did not change their registration to that of "non-practising member" when they were not employed: a total of one hundred and eighteen nurses (35\%). This figure is relatively high and will affect the number of professional nurses on the register of the SA Nursing Council.

What is the extent of the nurse's interest in the affairs of the nursing profession? Only forty-nine nurses voted for Council and Board members on the two statutory nursing bodies (14\%). The low voting rate of professional nurses was highlighted when the voting percentages for Council members were revealed in February 1984 Only $8,5 \%$ of all White professional nurses in the country had cast their vote. The President of the SA Nursing Council, commenting on the low voting rate, pointed out that in many countries nurses did not have the privilege of voting for those who determine the standards of the profession. To be worthy of her professional status, the registered nurse must take an interest in and accept responsibility for the affairs of their profession $(7$, p. 1$)$

\section{How actively does the nurse participate at branch level in the SA Nursing} Association?

A minimal number of nurses in the study reported that they attended their local branch meetings. The largest number of nurses only paid their membership fees and took no further interest in the affairs of their Association.

Reasons for non-attendance varied according to nursing field. Ranked in order from highest percentage response down, the following reasons had applied to less than one-hundred-and-thirty nurses in all practice areas $(40 \%)$ :

- It is irrelevant to my working situation. $40 \%$

- My family commitments do not permit me. $37 \%$

- I am doubtful about benefits to be gained. $36 \%$ 
- It is too risky to travel at night. $34 \%$

- I do not know anyone there. $30 \%$

- I do not believe in professional associations. $19 \%$

Other reasons which were reported by fewer than nine nurses $(3 \%)$ in each area of practice included such factors as:

- I have no transport at night.

- The meetings are boring/frustrating.

- I have not been invited.

- I have no idea where and when meetings are held.

Although a member of branches have made an attempt to overcome the difficulties posed by transport and meetings which are held at night by holding meetings at accommodating times, it is known that this has not increased the professional nurse's participation rate. It is evident that none of the reasons listed in the questionnaire, nor those given by the respondents, are the real cause of the apparent apathy by nurses toward their professional Association. In a study undertaken by Philip Marden on the rientations of registered nurses toward c American Nurses Association, he found that a lack of career dedication resulted in the alienation of nurses from American Nursing Association. Total career dedication is based on the willingness to recommend nursing as a career to one's daughter and friendly feelings toward one's colleagues. He found furthermore that "on-the-job dedication" had little or no effect upon commitment, as this refers to such characteristics as willingness to do more than is expected of one in the daily life on the job (3, p. 192).

The high percentage response to the factor "It is irrelevant to my work situation", suggests a lack of commitment to the affairs of their Association at this level, not becaue of perceived deficiencies in these meetings but merely because of indifference and presumed irrelevance to their current life circumstances. A disturbing factor which emerged was the umber of professional nurse immigrants ho reported that they were not aware of SANA meetings at this level and had no idea where these meetings were held.

What methods does the nurse use to keep professional knowledge and skills updated? The large majority of respondents in all five areas reported that reading professional literature was the only method used to keep their professional knowledge and skills updated (68\%). A small percentage of nurses made use of informal study methods $(27 \%)$ or had attended formal courses (9\%). Findings regarding fringe benefits revealed that few nurses had the privilege of undertaking formal studies in their work situation.

\section{Conclusions}

The registered nurse in the private sector has little interest in the activities of the SA Nursing Association, either at national or branch level, since few vote for board members while even fewer attend branch meetings. Apathy towards their professional Association is seen as indifference caused by current life styles since few nurses were found to be members of other social organisations or special interest nursing groups. Findings revealed that group cohesion is more evident in special interest groups such as the field of occupational health nursing: most of the sampled nurses working in

business/industrial health settings were members of the SA National Society of Occupational Health Nurses. Professional self-development tends to be minimal as few nurses attend nursing seminars/symposia or undertake formal courses as a form of continuing education. Most rely heavily on the reading of professional literature to keep their knowledge and skills upgraded. While inservice education programmes appear to be available in institutional health service settings, few nurses attend lectures on a regular basis.

\section{Recommendations}

- Employing authorities should institute in-service education programmes where required or else reappraise the efficacy of their current programme in order to encourage attendance.

- Employers should give registered nurses the opportunity to attend workshops, seminars or refresher courses so that they may upgrade their knowledge and skills with regard to the type of nursing service which they provide.

- Employers should provide opportunities for the professional nurse to become efficient in automation techniques since computers are in operation in many health agencies and will become common in most nursing areas.

- The SA Nursing Association should improve their image by highlighting the benefits offered to members other than negotiation. They should determine what the actual needs of the nurse who seeks assistance are.

\section{What is the extent of the nurse's} administrative managerial responsibilities? The largest percentage of professional nurses in the study were practising in hospital settings $(45 \%)$ - an environment in which it is generally assumed that the nurse in a leadership position on different management levels has the most administrative responsibilities. Findings revealed that professional nurses in all fields of nursing have numerous administrative responsibilities associated with managing human and material resources.

\section{What is the type and extent of} performance of administrative activities within each type of work environment? Twenty-two administrative activities directly concerned with the management of a work area were selected.

\section{Administrative activities concerned with} managing a nursing section

Responses indicated that the nurse employed in medical and dental practice settings with operating theatre facilities has the same organisational responsibilities as her colleagues in other areas of practice which provide patient care services. Of interest is that more than half the sample of nurses in each of the remaining practice areas performed the following activities:

- developing policies for the nursing area

- formulating nursing care objectives

- developing nursing care standards

- providing an effective system of recording and reporting

- providing and maintaining an effective communication system

- undertaking periodic inventories

- promoting good interpersonal relations

- reviewing and mediating staff conflicts.

From the analysis moreover it became apparent that only the nurse who is at the head of a service is concerned with budgeting activities. Responses revealed that a number of nurses are participating in research activities in each of the five areas of practice.

\section{Administrative activities associated with meeting direct/indirect patient needs} Eleven activities were listed. It was found that the professional nurse whose practice field lies within an institutionalised setting has relatively more administrative responsibilities concerned with meeting patient needs. Encounters with patients in ambulatory health care services are of a situational nature resulting in less administrative activities related to meeting patient needs.

\section{Personnel-centred activities}

Findings revealed, in addition, that the intensity of personnel administrative responsibilities the nurse has is influenced by the type and size of health service settings. Professional nurses in work environments where they are the only health care professional and have a smaller span of control performed relatively fewer personnel-centred activities.

\section{Activities associated with the general} management of supplies including other supervisory tasks

The professional nurse in charge is responsible for the ordering and general management of supplies in the nursing or health service unit. Findings revealed that most nurses in all five areas of practice were responsible not only for controlling material resources but also for undertaking other supervisory functions which are generally the task of ancillary service staff in large governmental hospitals.

A number of respondents in all practice areas reported that they were responsible for supervising the activities of nonnursing staff who provided patient support services. It was found that in all fields of nursing practice the nurse is responsible for the food-provision, laundry and cleaning services.

\section{Clerical and related secretarial duties}

Findings revealed that the nurse in custodial care settings has numerous clerical functions, apart from her extensive administrative responsibilities revealed in the foregoing. 
It is evident that clerical and related secretarial work is not restricted to the professional nurse in an office-based health service only. It was found that a number of nurses in all areas of practice in the private sector had secretarial-type responsibilities which included drawing and paying employee wages, bookkeeping, typing, banking money for the firm/practice, writing out receipts, and making patient appointments.

\section{Conclusions}

In all nursing fields in the private sector, excluding medical and dental office nursing settings, the registered nurse has extensive supervisory and administrative responsibilities associated with managing human and material resources in the work place. The type of administrative responsibilities performed by most nurses in private enterprise health service settings are those concerned with meeting direct/indirect patient needs and the general management of supplies. Nurses in the Cape, Natal, Transvaal and the OFS are not participating in the budgeting process. Budgeting is a means of directing efforts towards improving productivity since it reveals how well resources are utilised.

While clerical and secreterial tasks form a major part of the duties of the officebased nurses, these non-nursing activities are performed by a large proportion of nurses practising in all fields of nursing.

\section{Recommendations}

Employing authorities and employers should:

- encourage registered nurses to obtain management skills by offering, as a fringe benefit, to pay for the cost of subject fees for each nursing administration course passed at university level;

- involve nurses in the budgeting process since both inter- and intra-departmental activities and interpersonal contact broadens the experience of nurse managers;

- create opportunities for nurses to attend supervisory and management programmes. Professional seminars and workshops and management programmes are offered by continuing education department of various universities.

\section{What is the extent of the nurse's teaching role?}

Teaching is an important part of nursing care since the primary responsibility of every practising professional is to provide patients with quality health care and give guidance to those in need. The teaching role of the registered nurse implies responsibility towards the patient and the employing authority.

\section{How much and what type of teaching is undertaken?}

The large majority of nurses in all five areas of nursing practice reported that teaching was an important activity in their

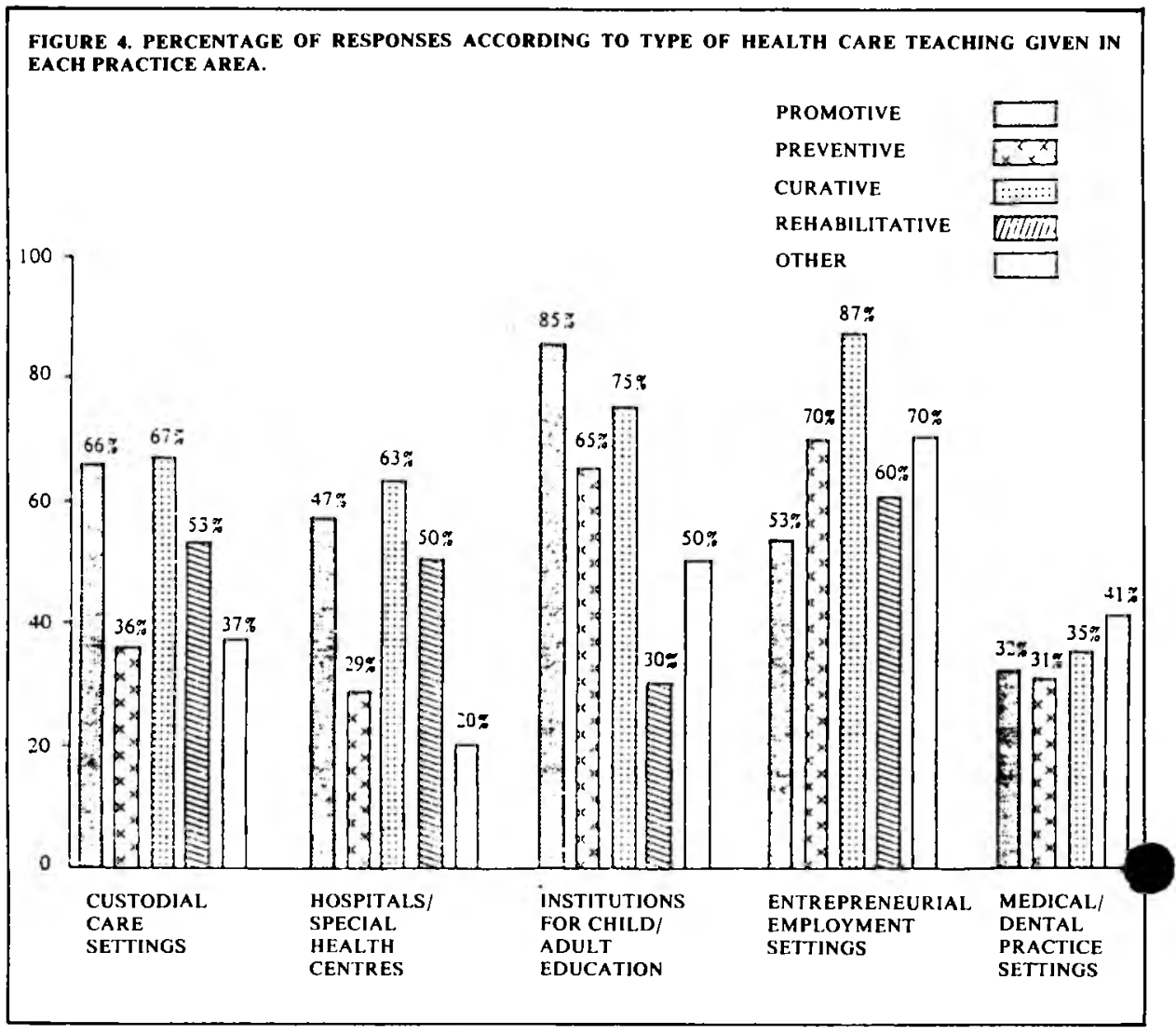

work field. Findings revealed, however, that relatively few nurses were actively involved with teaching people/groups with whom they had contact. Excluding the hospital based nurses and those in related curative care settings, most other professional nurses in the sample were in health care settings where patient care contact is incidental and on an ambulatory basis.

Although findings revealed that the people who benefited most from the teaching of the nurses in private health care settings were the aged and the nursing staff, teaching is not limited to one type of nursing field. Twenty-eight nurses in homes and institutions for the aged (8\%) always taught as a major part of their work, but responses indicated that nurses in other fields also teach aged citizens. Ten occupational health nurses indicated that they always teach business and industrial employees (3\%); however in other health fields nurses indicated that they also teach this category of worker. A number of respondents reported that they had teaching contact with people outside the immediate work place, such as with people in welfare groups/voluntary workers and community groups.

The type of health care teaching which was done in each practice field is illustrated in the column chart.

It was found that nurses employed by medical and dental practitioners do relatively little teaching in their practice setting. This is no doubt due to the amount of clerical and secretarial work which they are responsible for. It is evident that the teaching done by nurses in hospital settings is mainly curative.
Are nurses involved with in-service education?

A number of nurses in all five areas of practice reported that they were responsible for giving (33\%) or assisting with $(23 \%)$ in-service education when asked. Seventy-four respondents reported that it was the responsibility of their inservice department ( $22 \%$ ), while twentytwo percent did not have this type of staff development programme in their work environments. Findings revealed that few nurses attended in-service education lectures of professional interest.

It was found that more than half the sample of hospital-based nurses never attended in-service education lectures. This type of staff development programme has long been a part of hospital nursing services in the public sector and seems to identify and meet staff needs.

\section{Conclusions}

The nurse in the private sector acknowledges her teaching role but few are actively involved with teaching as most feel that this should be included in their job descriptions. Most nurses in all practice are as concentrate more on curative health care teching than do nurses in institutions for child and adult education; these latter nurses provide relatively more promotive health care teaching than do nurses in other work settings. Little active teaching is done by nurses in medical and dental office-based practice settings.

\section{Recommendations}

The nurse must:

- reappraise her role as teacher because teaching is an integral part of her 
professional responsibility;

- promote health education in the work setting as a main instrument for primary prevention;

- extend her educational function to include family teaching programmes;

- establish specific periods for active teaching in the work environment.

\section{Which nursing and related}

diagnostic/therapeutic activities does the nurse undertake?

Developments in health and medical services require nurses to fulfil a more extensive instrumental role based on a team relationship with the doctor and at times with other health service personnel.

\section{What kind of professional nursing activities are performed?}

A basic element in any field of nursing practice is the ability to assess health or illness. Physical appraisal skills enable the nurse to obtain qualitative information from which an accurate nursing diagnosis ay be made. Findings revealed that latively few nurses in private hospitals and special health care centres perform physical examinations on their patients

It was found that a number of nurses in medical consulting rooms other than those working in operating theatre units also examined patients in this way.

\section{What kind of diagnostic/therapeutic procedures are undertaken? \\ Of interest is the type of diagnostic/therapeutic activity which nurses performed as independent/interdependent nursing functions. It was found that activities which are generally performed by a radiographer and a number of medical diagnostic tests were performed by hospital-based nurses and the nurse who is working in a medical practice setting. Only four percent of the nurses in the sample were actively involved with family \\ anning.}

\section{Conclusion}

The main type of nursing care provided in all health care settings is basic nursing care. Few nurses hold post-registration qualifications which enable them to give specialist nursing care. Rehabilitative nursing care forms a small part of the nursing care provided. A number of nurses performed activities in private hospitals and in medical practice settings which are medical diagnostic procedures. Although the professional nurse who performed these acts appears to have accepted a specific prescription or direction from the doctor for these procedures and appears to have made an independent decision, this nurse must accept full responsibility and remains accountable for her actions.

\section{Recommendation}

Employing authorities and employers should utilise the professional knowledge and skills of the nurse by giving her as much clinical responsibility as she seeks and is able to cope with.

\begin{tabular}{|c|c|c|c|c|c|c|}
\hline Authority level & $\begin{array}{l}\text { Custodial } \\
\text { care settings } \\
(N=76)\end{array}$ & $\begin{array}{c}\text { Hospitals/ } \\
\text { special health } \\
\text { centres } \\
(N=152)\end{array}$ & $\begin{array}{l}\text { Institutions } \\
\text { for child/ } \\
\text { adult } \\
\text { education } \\
(\mathbf{N}=20)\end{array}$ & $\begin{array}{c}\text { Entrepre- } \\
\text { neurial } \\
\text { practice } \\
\text { settings } \\
(N=\mathbf{3 0})\end{array}$ & $\begin{array}{c}\text { Medical/ } \\
\text { Dental } \\
\text { practice } \\
\text { settings } \\
(N=62)\end{array}$ & Total \\
\hline Proprietorship & 6 & 3 & 1 & 1 & 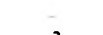 & $11(3 \%)$ \\
\hline Top-level manager & 16 & 4 & 1 & 1 & 3 & $25(7 \%)$ \\
\hline Mid-level manager & 12 & 29 & 4 & 12 & 6 & $63(19 \%)$ \\
\hline First-level manager & 20 & 41 & 5 & 3 & 6 & $75(22 \%)$ \\
\hline Professional service-level worker & 22 & 75 & 9 & 13 & 47 & $166(49 \%)$ \\
\hline Total & 76 & 152 & 20 & 30 & 62 & $340(100 \%)$ \\
\hline
\end{tabular}

What is the nursing role structure within the practice area?

To determine the nursing role structure within each of the thirteen fields of nursing, respondents were requested to indicate what level of authority they attached to the post occupied.

How much responsibility and authority is attached to the post occupied?

Findings revealed that five distinct authority levels emerged in each practice field, excluding medical and dental practice settings. (See Table IV)

Almost half the sample of nurses were employed as professional service level workers with no supervisory responsibilities other than patient care or secretarial duties in medical and dental office practice settings.

How confident is the nurse about selected professional practice aspects?

Respondents reported that most had complete responsibility for deciding how and when their work was done. Of interest is that, while most nurses were confident of aspects related to professional practice this item in the questionnaire received the highest non-response scores, reflecting uncertainty on the part of the respondents.

Findings revealed that the largest percentage of nurses in the study reported that they were uncertain of the way in which nursing policy decisions, rules and regulations were made and how their work was evaluated. This reflects a breakdown in communication between top management and employee. The percentage of nurses who are uncertain of activities that are dependent upon a doctor's prescription is noteworthy.

\section{Conclusions}

Nurses in private sector health services function on five levels of management: proprietorship, top-level, mid-level, firstlevel and service-level. The largest proportion of nurses in the study revealed that the authority and responsibility attached to the post occupied was that of a professional service-level worker. These nurses are mainly responsible for giving direct patient care and have few supervisory responsibilities. While a large number of professional nurses in the private sector have job descriptions and are confident of professional practice aspects related to decision-making, authority and responsibility in the work place, a number of nurses are uncertain of how their work is evaluated and how decisions concerning nursing policies and regulations are made.

\section{Recommendations}

Employing authorities and employers should:

- provide policy manuals which are updated at regular intervals and are used as in-service and staff development tools in work settings, where these are not available;

- introduce the constructive performance appraisal method which is appropriate for most health care institutions. The nurse will know well in advance the basis for evaluation if she has already participated in establishing the objectives;

- consider using self-appraisal methods along with the existing appraisal system to gain insight into employee strengths and weaknesses;

- provide job descriptions which outline administrative, teaching and professional responsibilities in settings where these are not available.

\section{CONCLUDING REMARKS}

This has been an exploratory study in which an attempt was made to develop a profile of professional nursing practise in private health services in this country. The registered nurse in private enterprise is currently providing essential health care services in all forms of private organisations. It is hoped that the findings will provide answers for future health service planning in the private sector and create a more co-operative relationship between private and public health care sectors. While health providers benefit from the utilisation of the nursing skills of registered nurses, of greater importance is the benefit to society from the comprehensive nursing care which can be provided by this highly qualified health care professional. Employing authorities should provide avenues for the registered nurse to upgrade her knowledge and expand her services to meet the health care challenge. 
Acknowledgement

I wish to acknowledge the financial assistance received from the Human Sciences Research Council in this study.

BIBLIOGRAPHY

I. Cilliers, G. 1983. Beroepstudies van Verpleegkundiges: Werksiruasie van Geregisireerde Verpleegkundiges (Deel 2 ) RGN Verslag No. MM - 94 1983. Pretoria: Raad vir Geesteswetenskaplike Navorsing.

2. Fagin, C.M. 1982. The National Shortage of Nurses: A
Nursing Perspective, in Nursing in the 1980 's. Edited by Aiken, L.N. Philadelphia: J.B. Lippincolt Company.

3. Marden, P W. 1983. Orientarions of Registered Nurses Toward their Professional Association. Illinois: University of illinois.

4 Montagna, P.D. 1977. Occupations and Society. New York John Wiley and Sons.

5. The SA Nursing Association, 1985. Repori on the Nursing Service and Nursing Education in the Republic of South Africa, 1979-1982. Pretoria: SANA.

6. Ithe SA Nursing Council, 1983. Statistical Returns for the Calendar Year 1983. C21M84 (B)

7. Röscher, C.I 1984. Voting percentage most disturhing, in Nursing News. Vol 8 No I February Official Newspaper of the SA Nursing Association.
Silvia Angelina Pera

D.Cur, R.N., R.M., R.T., R.N.A., R.C.N. Dip. Orth. N. Cert. Spinal Injuries $N$.

(Stoke Mandeville)

Professor of Nursing

University of South Africa

This article is based on research underiaken

in 1983 for the degree of Doctor Curationis

with the University of Port Elizabeth

with Prof. Dr. W.J. Kotzé as promoter

\section{Erratum}

Curationis Vol. 11 No. 1: Artikel - S. van Tonder

Hierdie studie vir

Doktorsgraaddoeleindes aan die U.P.E.

is gedoen onder promotorskap van

professor dr. W.J. Kotzé.

Professor Kotzé was mede-outeur. 